\title{
Części zmienne Mszy św. w przekładzie: wybrane kolekty w dwóch angielskich wersjach Novus Ordo Missae
}

\section{Mass propers in translation: selected collects in two English versions of Novus Ordo Missae}

\author{
Wiktor Pskit \\ Wydział Filologiczny, Uniwersytet Łódzki, \\ ul. Pomorska 171/173, 90-236 Łódź, Polska; \\ email: pskit@vp.pl
}

\begin{abstract}
Abstrakt
Artykuł dotyczy przekładu tekstów liturgii rzymskokatolickiej. Przedstawia tło historyczne posoborowej reformy liturgicznej, której istotnym elementem była zmiana języka celebracji z łaciny na języki narodowe. Omawia również dokumenty Kościoła, które stanowiły podstawę dla dokonywanych przekładów mszału Pawła VI. Główną część artykułu stanowi porównanie dwóch różnych wersji mszału rzymskiego w przekładzie na język angielski, tj. wersji z 1973 roku oraz 2010 roku, ze szczególnym uwzględnieniem wybranych kolekt. Opracowanie wskazuje, że o ile wcześniejsze tłumaczenie angielskie odchodzi od hieratycznej natury języka liturgii, nowszy przekład stanowi próbę powrotu do stylu sakralnego. Wnioski zawierają też krótką refleksję na temat realizacji postanowień Soboru Watykańskiego II w odniesieniu do liturgii w kontekście omówionych w artykule angielskich wersji tekstów mszalnych.
\end{abstract}

Słowa kluczowe: język liturgii; przekład; język narodowy; części zmienne; kolekta; Mszał Pawła VI.

\begin{abstract}
The paper is concerned with the translation of Roman Catholic liturgical texts. It presents the historical background of the post-conciliar liturgical reform involving a significant change in the language of liturgy: the shift from Latin to the vernacular. It also discusses Church documents that guided the translation of Paul VI's Missal into vernaculars. The main part of the paper is devoted to a comparison of the two English translations of the reformed Roman Missal, i.e. the 1973 and 2010 versions, with a particular focus on the selected collects. It is demonstrated that while the earlier translation moves away from the hieratic nature of liturgical language, the more recent version attempts to return to the sacral style. In conclusion, it also reflects on whether the relevant translations truly implement what the Second Vatican Council postulates with respect to liturgy.
\end{abstract}

Keywords: liturgical language; translation; vernacular; propers; collect; Paul VI's Missal. 


\section{Wstęp}

Niniejszy artykuł dotyczy thumaczenia języka liturgii rzymskokatolickiej na przykładzie angielskiego wydania mszału Pawła VI. Od czasu reformy liturgii dokonanej po Soborze Watykańskim II nieprzerwanie trwa debata na temat języka liturgii rzymskokatolickiej. Dyskusja odbywa się głównie na dwóch płaszczyznach: pierwsza dotyczy samego odejścia od łaciny na rzecz języków narodowych, a druga formy językowej tekstów liturgicznych w tychże językach narodowych. Jednocześnie wspomniane płaszczyzny wydają się na siebie zachodzić, jeśli weźmie się pod uwagę fakt, iż wersje wernakularne z założenia są tłumaczeniem łacińskiej edycji typicznej mszału Pawła VI.

$\mathrm{W}$ artykule przedstawione zostanie tło historyczne angielskiego przekładu tekstów liturgicznych, w tym wytyczne ujęte w dwóch różnych instrukcjach dotyczących tłumaczenia tego mszału. Zwrócimy uwagę na daleko idące różnice pomiędzy kształtem językowym angielskich tłumaczeń tekstów mszalnych $\mathrm{z}$ lat 70. XX wieku oraz z roku 2010. Różnice te dotyczą zarówno części stałych, jak i zmiennych Mszy św., przy czym skupimy się przede wszystkim na tych drugich i omówimy na przykładzie kilku wybranych kolekt.

\section{Posoborowa reforma liturgiczna: języki narodowe w liturgii}

Postulowana w konstytucji Soboru Watykańskiego II, Sacrosanctum concilium (1963), odnowa liturgii rzymskiej miała uwzględnić wprowadzenie do obrzędów języków narodowych. Wprawdzie, na co niejednokrotnie zwracano uwagę (por. m.in. Gamber 1992, Lang 2012, Milcarek 2009, Zachara 2014), dokument ten wskazywał na ograniczony zakres użycia języka narodowego, ale wdrożenie reformy liturgii skutkowało w praktyce wyrugowaniem łaciny i całkowitym zastąpieniem jej przez języki narodowe. Należy jednocześnie pamiętać, że ogłoszony przez Pawła VI w 1969 roku zreformowany mszał to tekst łaciński. On też miał stanowić punkt wyjścia do przygotowania wersji w językach narodowych. Od tego czasu Kościół boryka się z problemem przekładu ksiąg liturgicznych, co czasem przeradza się w to, co potocznie bywa określane mianem „wojen liturgicznych”. Owe „wojny” nie ograniczają się wyłącznie do języka celebracji, ale nierzadko również jego dotyczą.

Początki zreformowanej liturgii wiązały się z różnymi podejściami do kwestii thumaczenia tekstów zawartych w nowym mszale rzymskim. Ponadto sytuacji nie ułatwiał brak jednoznacznych wytycznych ze strony stanowiącej prawo w sferze liturgii Stolicy Apostolskiej. Samo dopuszczenie języków narodowych do liturgii rzymskiej dokonało się na mocy instrukcji Inter oecumenici (1964) wydanej przez Consilium, ciało powołane przez Pawła VI w celu wdrożenia postanowień soborowej konstytucji o liturgii (Sacrosanctum concilium, 1963). Powołując się na punkt 36 wspomnianej konstytucji, instrukcja ta ustanawiała normy dla przygotowania wernakularnych wersji tekstów mszalnych. Po pierwsze, podstawą thuma- 
czeń miał być łaciński tekst edycji typicznej, a w samym procesie przekładu mieli brać udział liturgiści, bibliści, znawcy języków biblijnych, łaciny i poszczególnych języków narodowych, a także eksperci z dziedziny muzyki. Kolejne wskazanie zalecało wspólne konsultacje biskupów z regionów i krajów posługujących się tym samym językiem. Z kolei dla krajów, w których używa się więcej niż jednego języka, należało przygotować tłumaczenie na każdy z języków. Wreszcie instrukcja kładła nacisk na potrzebę przygotowania tekstów wernakularnych wysokiej jakości. Trzymając się jeszcze wskazań soborowej konstytucji Sacrosanctum concilium (1963), dokument przewidywał, że Kanon rzymski pozostanie po łacinie. Możliwość używania języka narodowego w kanonie Mszy św. została wprowadzona w późniejszej instrukcji Świętej Kongregacji ds. Rytów Tres abhinc annos (1967), przyznającej władzę decydowania o tym konferencjom biskupów. W punkcie 57 instrukcja Inter oecumenici zastrzegała, że mszał używany do sprawowania obrzędów liturgicznych obok tekstu wernakularnego ma zawierać łaciński oryginał. Wbrew temu ostatniemu zaleceniu, tzw. przejściowy mszał opublikowany w Stanach Zjednoczonych w roku 1964 i stosowany od I niedzieli Adwentu tegoż roku nie zawierał wersji łacińskiej, a jedynie thumaczenie angielskie. O konsekwencjach tego swoistego zniknięcia z horyzontu tekstów łacińskich przekonamy się na przykładzie analizowanych poniżej przykładów modlitw.

Wskazania podobne do tych zawartych w Inter oecumenici znalazły się również w skierowanym do tłumaczy tekstów liturgicznych wystąpieniu Pawła VI z 10 listopada 1965 roku Papież wspomniał w swym przemówieniu o tym, że język obrzędów powinien odpowiadać „godności sprawowanych czynności”, powinien on być różny od „codziennej mowy ulicy i placu targowego”, jak również o tym, iż wersje wernakularne powinny odzwierciedlać klarowność i godność języka tekstów liturgicznych (Lang 2012: 160-161). Znowu zaznaczmy, że jeden z poniżej analizowanych przekładów pokaże, jak dalece autorzy tekstu angielskiego potrafili odejść od zaleceń Stolicy Apostolskiej.

Po swoistym okresie prób i eksperymentów wraz z opublikowaniem owoców prac Consilium, czyli zreformowanego mszału rzymskiego (1969/1970), pojawiła się potrzeba opracowania jego tłumaczeń na języki narodowe. Zbiorem wytycznych w tym zakresie miała być pierwotnie instrukcja Comme le prévoit (25 stycznia 1969), opracowana przez komisję przygotowującą nowy mszał. W pewnych aspektach dokument ten powtarza to, co zawierają wyżej wspomniane instrukcja Inter oecumenici (1964) oraz przemówienie Pawła VI. Jest w nim mowa o „godnym stylu” i „tradycyjnym języku religijnym”. W dalszej części jednak pojawiają się całkiem nowe postulaty, które w kontekście wcześniejszych wskazań mogą się wydawać dosyć „rewolucyjne”. Mianowicie Comme le prévoit (1969) wzmiankuje o tym, iż oddanie treści niekoniecznie musi się odbywać przy zachowaniu formy językowej oryginału, co wydaje się być echem ówczesnych trendów przekładoznawczych, zwłaszcza ekwiwalencji dynamicznej Eugene’a Nidy (1964). Tym, co - przynajmniej w kontekście anglojęzycznym - okaże się brzemienne w skutki, jest dopuszczenie przez ten dokument pewnego zakresu adapta- 
cji. Co jednak najciekawsze, z prawnego punktu widzenia instrukcja Comme le prévoit nigdy nie stała się dokumentem obowiązującym w Kościele i pozostała wewnętrznym dokumentem roboczym Consilium. Wskazują na to następujące fakty: instrukcja ta powstała w języku francuskim i nigdy nie przetłumaczono jej na łacinę, a sam tekst nie został nigdy opublikowany w Acta Apostolicae Sedis, oficjalnym organie Stolicy Apostolskiej. Mimo tego, w krajach anglojęzycznych to właśnie część zasad z Comme le prévoit stanowiła podstawę dla przygotowania angielskiego przekładu mszału Pawła VI.

$\mathrm{Z}$ uwagi na to, że językiem angielskim posługują się katolicy w wielu krajach na różnych kontynentach, na potrzeby przygotowania spójnej wersji mszału w języku angielskim powołano wspólną dla kręgu języka angielskiego komisję International Committee for English in the Liturgy (odtąd ICEL). Wkrótce okazało się, że ciało to zostało zdominowane przez zwolenników dopuszczonych przez Comme le prévoit zasad ekwiwalencji dynamicznej. Ekwiwalencja dynamiczna kładzie nacisk na sam przekaz znaczenia, ignorując związek pomiędzy formą wyrażeń językowych i ich znaczeniem. Takie rozumienie przekładu otwiera przed tłumaczem dosyć szerokie pole dla interpretacji znaczenia tekstu oryginalnego. O ile ekwiwalencja dynamiczna może dać ciekawe owoce w przypadku wielu gatunków tekstów, o tyle w przypadku tekstów liturgicznych dopuszczenie takiej swobody interpretacyjnej wydaje się wysoce ryzykowne. $Z$ rezultatami zastosowania ekwiwalencji dynamicznej zapoznamy się w części 4. niniejszego opracowania.

Warto tu wspomnieć o języku liturgicznym w perspektywie językoznawczej. Spośród językoznawców o języku liturgicznym szeroko pisała Christiane Mohrmann, holenderska badaczka wczesnochrześcijańskiej greki i łaciny. Pisząc o języku liturgii rzymskiej, Mohrmann zwraca uwagę na jego hieratyczny (sakralny) charakter (1959; 1977). Do najważniejszych cech języka hieratycznego zalicza ona przywiązanie do starszych form językowych (archaizacja), wprowadzanie elementów obcych (zapożyczenia) oraz użycie figur retorycznych typowych dla stylu mówionego. Ta ostatnia cecha wydaje się szczególnie ważna w kontekście liturgii rzymskiej, której język w pewnej mierze jest spadkobiercą rzymskiego stylu oratorskiego. Mohrmann podkreśla rozbieżności pomiędzy językiem sakralnym i językiem codziennej komunikacji. Ten pierwszy jest przynajmniej w pewnej mierze produktem sztucznym, podczas gdy ten drugi wykazuje tendencję do uproszczenia i standaryzacji. To skłania Mohrmann do rozróżnienia pomiędzy łaciną liturgiczną i tą używaną w codziennej komunikacji w kontekście wczesnochrześcijańskim. Twierdzi ona, iż łacina zastąpiła w liturgii grekę dopiero wtedy, gdy wykształciła się jej odpowiednio stylizowana odmiana hieratyczna. Co więcej, w swych publikacjach ${ }^{1}$, które czasowo zbiegają się z okresem bezpośred-

${ }^{1}$ Do niedawna publikacje C. Mohrmann były niedostępne w języku polskim. Praca Liturgical Latin: Its Origins and Character (1959) doczekała się polskiego wydania (Łacina liturgiczna - jej początki i charakter. Trzy wykłady) w przekładzie Tomasza Dekerta opublikowanego w trzech częściach w kolejnych numerach kwartalnika Christianitas (56-57/2014, 58/2014, 59/2015). 
nio przed posoborową reformą liturgiczną i tuż po niej, holenderska badaczka zauważa, że na ówczesnym etapie swego rozwoju języki wernakularne nie wykształciły jeszcze stylu hieratycznego.

W podobnym tonie, ale na gruncie języka angielskiego o hieratyczności tekstów liturgicznych pisze między innymi znany językoznawca David Crystal (1964; 1990). Wśród elementów, jakie według niego powinna zawierać liturgiczna angielszczyzna, wymienia on archaiczne formy gramatyczne (np. przejawiające większe bogactwo fleksyjne starsze formy zaimków dla 2 os. 1. poj. thou, thee, thy, thine, ye zamiast współczesnego you, starsza forma fleksyjna czasownika art zamiast współczesnego are, czy archaiczna forma 1. mn. brethren 'bracia' zamiast brothers), archaizmy leksykalne (np. vouchsafe 'raczyć udzielić', thrice 'trzykroć', behold 'oto', dosł. 'ujrzeć, spojrzeć'), a także określone struktury składniowe (nietypowy szyk zdania, częste formy wołacza, tryb rozkazujący z podmiotem).

Wspomniana wyżej metodologia oparta na zasadach ekwiwalencji dynamicznej zaowocowała pierwszym oficjalnie zaaprobowanym angielskim przekładem mszału rzymskiego z roku 1973. Tłumaczenie to charakteryzuje się odejściem od języka hieratycznego (brak archaizmów, brak bardziej złożonych wyszukanych form składniowych), tendencją do uwspółcześniania czy wręcz kolokwializacji i banalizacji języka liturgii, a także szeregiem pominięć w stosunku do łacińskiego oryginału. Widzimy tu spory rozdźwięk pomiędzy wynikami badań Mohrmann i Crystala a podejściem preferowanym przez członków ICEL. Wymienione cechy angielskich tekstów liturgii rzymskiej stały się przedmiotem sporów i wielu krytycznych komentarzy, zaś kształt językowy angielskiego mszału z roku 1973 bywa uznawany za przykład nadużyć w dziedzinie liturgii (por. m.in.: Schuler 1981; Elliot 2007; Pell 2014).

\section{Trzecia edycja mszału rzymskiego i korekta przekładów}

W następstwie zarządzonej przez Jana Pawła II rewizji mszału rzymskiego w roku 2002 ukazało się jego trzecie wydanie. Jednocześnie papież polecił dokonanie korekty tłumaczeń, która miała się opierać na specjalnie w tym celu opracowanej nowej instrukcji Liturgiam authenticam (2001). Istotnym elementem nowych zarządzeń watykańskich jest to, że wszelkie księgi liturgiczne, zanim wejdą do użytku, muszą uzyskać oficjalne zatwierdzenie ze strony Stolicy Apostolskiej. Instrukcja Liturgiam authenticam zawiera wiele wskazań mających doprowadzić do wyeliminowania niedoskonałości wersji wernakularnych. Kładzie ona między innymi nacisk na czytelny przekaz doktrynalny $\mathrm{w}$ tekstach mszalnych, które mają być opracowane tak:

[...] aby odznaczały się zdrową doktryną, były dokładne w wypowiedziach, wolne od jakiegokolwiek wpływu ideologicznego i posiadały takie właściwości, dzięki którym święte tajemnice zbawienia i nienaruszona wiara Kościoła znajdują skuteczny wyraz 
w modlitwie formułowanej w ludzkim języku, a Najwyższemu Bogu składany jest właściwy kult (Liturgiam authenticam, 2001, nr 3).

Do kwestii spójnego przekazywania nauki Kościoła wraca się też w punkcie 26 instrukcji: „Przekład tekstów powinien być zgodny ze zdrową nauką” (Liturgiam authenticam, 2001).

W osobnym punkcie pojawia się bezpośrednie odniesienie do nadużyć liturgicznych natury językowej:

[...] zauważa się, że przekłady tekstów liturgicznych w różnych miejscach wymagają jeszcze ulepszenia poprzez ich skorygowanie lub opracowanie ich nowej redakcji [...] Opuszczenia albo błędy, jakimi niektóre przekłady na języki narodowe nadal są obciążone, utrudniły w rzeczywistości należyty postęp procesu inkulturacji, zwłaszcza gdy chodzi o niektóre języki. Wskutek tego Kościół utracił możliwość wznoszenia podwaliny pod pełniejszą, bardziej zdrową i prawdziwą odnowę (Liturgiam authenticam, 2001, nr 6).

Innym ważnym aspektem jest konieczność dochowania wierności łacińskiemu oryginałowi, przestrzeganie zasady „organicznego rozwoju liturgii” (por. Reid 2005; Ratzinger 2002; Milcarek 2009), unikania opuszczeń bądź dodatków względem oryginału oraz ograniczenie wszelkich zabiegów adaptacyjnych:

Ponieważ liturgiczne teksty łacińskie obrządku rzymskiego czerpią z wieków kościelnego doświadczenia w przekazywaniu wiary Kościoła otrzymanej od Ojców, same są świeżym owocem liturgicznej odnowy. Aby tak wielkie i bogate dziedzictwo zachować oraz przekazywać dalej przez wieki, należy przede wszystkim mieć na uwadze zasadę, że przekład tekstów liturgicznych liturgii rzymskiej ma być nie tyle dziełem artystycznym, ile raczej wiernym i dokładnym oddaniem w języku narodowym oryginalnych tekstów. Chociaż wolno korzystać ze swobody w doborze słów oraz stosować składnię i styl odpowiednie do tekstu w języku narodowym i do toku mowy, który jest właściwy dla języka ojczystego, to jednak wypada, aby tekst oryginalny, czyli pierwotny, na ile to możliwe, był thumaczony bardzo wiernie i bardzo dokładnie, a mianowicie bez jakichkolwiek opuszczeń albo dodatków, co do jego treści, oraz bez wprowadzania parafraz i glos; przystosowanie tekstu do właściwości i przymiotów różnych języków narodowych powinno być nieznaczne i przeprowadzone ostrożnie (Liturgiam authenticam, 2001, nr 20).

Teksty w językach narodowych mają być zrozumiałe, przy jednoczesnym zachowaniu dostojnego stylu podkreślającego piękno modlitw.

Aby treści tekstu oryginalnego stały się dostępne i zrozumiałe również dla wiernych nie mających specjalnego wykształcenia intelektualnego, właściwością przekładów winno być słownictwo umożliwiające ich zrozumienie, ale zachowujące równocześnie godność, piękno i dokładną treść doktrynalną tego rodzaju tekstów. Przez słowa pochwały i adoracji, które przyczyniają się do wyrażenia czci i wdzięczności względem majestatu Boga, Jego potęgi i miłosierdzia oraz Jego transcendentnej natury, tłumaczenia będą zaspokajać głód i pragnienie Boga żywego, których doświadcza współczesny 
lud, a równocześnie podkreślą godność i piękno samej celebracji liturgicznej (Liturgiam authenticam, 2001, nr 25).

Wreszcie, kierowanie się nakreślonymi przez instrukcję wytycznymi ma pomóc w wypracowaniu hieratycznego stylu dla poszczególnych języków wernakularnych: „wydaje się nawet, że przestrzeganie zasad przedstawionych $\mathrm{w}$ tej instrukcji przyczyni się stopniowo do wytworzenia w każdym języku narodowym sakralnego stylu, który mógłby być uznany za język ściśle (proprie) liturgiczny" (Liturgiam authenticam, 2001, $\mathrm{nr} 27$ ).

Podstawowym wymaganiem, jakie instrukcja Liturgiam authenticam stawia językowi liturgii, jest zatem hieratyczność, od której - jak wspomnieliśmy - autorzy angielskiego przekładu z 1973 roku starali się jak najdalej odejść, a do której z kolei dążyli twórcy nowego thumaczenia z roku 2010.

\section{Mszał rzymski w języku angielskim}

Jeśli chodzi o części stałe Mszy św., to ważniejsze różnice językowe pomiędzy angielskimi wydaniami tekstów liturgicznych z lat 1973 (International Commission on English in the Liturgy, 1973) oraz 2010 (International Commission on English in the Liturgy, 2010) omówiono w osobnym opracowaniu (Pskit 2018). Tutaj pokrótce o nich wspomnimy w celu nakreślenia tła dla analizy wybranych części zmiennych. Oczywiście, trzeba pamiętać, że są to teksty, z którymi uczestnicy celebracji obcują najczęściej. Do najczęściej wspominanych różnic należy zaliczyć odpowiedź wiernych na kilkukrotnie powtarzane przez kapłana wezwanie ,the Lord be with you' ('Pan z wami'). Przez kilkadziesiąt lat obowiązywała pozbawiona transcendentnego odniesienia odpowiedź „And also with you” (dosł. 'I również z tobą'), którą zmieniono na znacznie bliższą oryginałowi wersję „And with your spirit" ('I z duchem twoim'). Rozpoczynający mszalne Credo zaimek miał formę liczby mnogiej w przekładzie z 1973 roku (We believe - dosł. 'wierzymy'), obecnie obowiązuje forma liczby pojedynczej I believe ('wierzę'). Innym przykładem jest zawarty w modlitwie eucharystycznej zwrot pro multis. Dyskusje na temat jego przekładu mają podłoże doktrynalne i dotyczą teologicznego rozróżnienia pomiędzy pojęciami Zbawienia i Odkupienia. W tłumaczeniu z 1973 roku pro multis to w języku angielskim for all (dosł. 'za wszystkich'), zaś w trzeciej edycji mszału rzymskiego powraca się do wiernego i doktrynalnie poprawnego brzmienia for many (dosł. 'za wielu').

Kontrast pomiędzy słownictwem z języka codziennego (w wyd. z 1973 r.) i bardziej wyszukanymi, archaicznymi formami w nowszym wydaniu mszału (2010) to choćby angielski odpowiednik kielicha w formule konsekracji wina: wcześniej cup (dosł. 'filiżanka, kubek, puchar'), a teraz chalice (dosł. 'kielich'), będące zapożyczeniem z łaciny (calix).

Kolejny przykład banalizacji języka znajdujemy w wezwaniu kapłana będącym częścią obrzędu Komunii, brzmiącym w oryginale: „Ecce Agnus Dei, ecce 
qui tollit peccata mundi. Beati qui ad caenam Agni vocati sunt”. Po polsku: „Oto Baranek Boży, który gładzi grzechy świata. Błogosławieni, którzy zostali wezwani na Jego ucztę". Starsza wersja angielska miała postać (fragmenty różniące się od przekładu z 2010 r. podkreślono): „This is the Lamb of God who takes away the sins of the world. Happy are those who are called to his supper" (dosł. 'To jest Baranek Boży, który gładzi grzechy świata. Szczęśliwi ci, którzy są wezwani na Jego ucztę'). W najnowszym wydaniu angielskim posłużono się bardziej rozwiniętym i zawierającym archaizmy ekwiwalentem: „Behold the Lamb of God, behold him who takes away the sins of the world. Blessed are those called to the supper of the Lamb" (dosł. 'Oto Baranek Boży, oto Ten, który gładzi grzechy świata. Błogosławieni ci, którzy zostali wezwani na ucztę Baranka'). Uderza tu w szczególności zmiana trącącego trywialnością przymiotnika happy 'szczęśliwy' na blessed 'błogosławiony', jak również próba wierniejszego oddania łacińskiego oryginału z powtórzeniem ecce/behold.

\section{Wybrane części zmienne w angielskim przekładzie mszału Pawła VI: wersje z 1973 roku oraz 2010 roku}

W poniżej prezentowanych fragmentach tekstów liturgicznych posługujemy się następującymi skrótami: MR dla edycji typicznej po łacinie (stanowiącej tu „oryginał”, tekst wyjściowy), ICEL 1973 (starsze thumaczenie angielskie), PL 1986 (aktualnie używane thumaczenie polskie) oraz ICEL 2010 (nowy przekład angielski). Tekst polski pochodzi z Mszatu rzymskiego dla diecezji polskich z roku 1986, czyli jest tłumaczeniem wcześniejszej edycji typicznej, a nie tej najnowszej z roku 2000. Uwzględnienie tej wersji jest uzasadnione, gdyż po pierwsze jest ona nadal w użytku (prace nad nowym wydaniem polskim nadal trwają), a po drugie zestawienie polskiego tekstu $\mathrm{z}$ dwoma thumaczeniami angielskimi dostarcza interesujących obserwacji. Już pobieżny rzut oka pozwala zauważyć, iż większe podobieństwo pod względem treści i stylu istnieje pomiędzy polskim tłumaczeniem i nowszym przekładem angielskim (ICEL 2010). Starsza wersja angielska (ICEL 1973) wyraźnie odstaje pod tym względem zarówno od oryginału (MR), jak i od obu pozostałych przekładów. Obie wersje angielskie opatrzono literalnym thumaczeniem na język polski (w nawiasach kwadratowych). Fragmenty (pojedyncze wyrazy bądź dłuższe zwroty), które odzwierciedlają kluczowe różnice i które są przedmiotem analizy, zostały podkreślone.

Choć przedstawione poniżej przykłady mają wyrywkowy charakter, obrazują one wspomniane wcześniej rozbieżne tendencje w dwóch angielskich tłumaczeniach. $Z$ uwagi na ograniczone rozmiary niniejszego opracowania wspomnimy o najważniejszych różnicach pomiędzy dwoma wydaniami angielskimi mszału Pawła VI, pamiętając jednocześnie, że zarówno omawiane poniżej wybrane fragmenty, jak i cała zawartość obu przekładów (ICEL 1973 oraz 2010) domaga się pogłębionej analizy, zwłaszcza w odniesieniu do łacińskiego oryginału. 
Do istotnych części zmiennych Mszy św. należy kolekta, czyli modlitwa odmawiana przez celebransa przed pierwszym czytaniem z Pisma świętego. Kolekta ma określoną strukturę i składa się z początkowego odniesienia do Boga, wspomnienia wielkich dokonań Boga, skierowanej do Boga prośby i kończącej kolektę formuły trynitarnej. Taka struktura w dużym stopniu narzuca pewne formy językowe. W przypadku kolekt w łacińskiej edycji typicznej zreformowanego mszału, ich opracowanie nierzadko sprowadzało się z jednej strony do redukcji tekstu kolekty w jej wersji sprzed reformy (tj. w mszale rzymskim z 1962 r.), a z drugiej strony do przeniesienia danej kolekty na inny termin w kalendarzu liturgicznym ${ }^{2}$. Przykładowo, kolekta na XI niedzielę zwykłą według nowego kalendarza jest zmodyfikowaną wersją kolekty z I niedzieli po Zesłaniu Ducha Świętego według starszego kalendarza ${ }^{3}$. W omawianych przykładach kolekt pomijamy powtarzającą się formułę trynitarną, choć jej przekład również może dostarczyć pola do dyskusji. Kolekta na II niedzielę zwykłą wygląda następująco:

\section{MR}

Omnipotens sempiterne Deus, qui caelestia simul et terrena moderaris, supplicationibus populi tui clementer exaudi, et pacem tuam nostris concede temporibus.

\section{ICEL 1973}

Father of heaven and earth, hear our prayers, and show us the way to peace in the world.

['Ojcze nieba i ziemi, wysłuchaj nasze modlitwy i wskaż nam drogę do pokoju na świecie’]

\section{PL 1986}

Wszechmogący, wieczny Boże, Ty rządzisz niebem i ziemią, wysłuchaj łaskawie prośby swojego ludu i obdarz nasze czasy swoim pokojem.

\section{ICEL 2010}

Almighty ever-living God, who govern all things, both in heaven and on earth, mercifully hear the pleading of your people and bestow your peace on our times.

2 Czasem komentatorzy pozwalają sobie na ironiczne uwagi, według których praca redaktorów kolekt do Mszału Pawła VI polegała głównie na „cięciu” wcześniejszych tekstów tych modlitw, a następnie „sklejaniu” tak „pociętych” kawałków. Kulisy tych działań do pewnego stopnia odsłaniają opracowania i opublikowane wspomnienia uczestników prac - zarówno te pisane w tonie apologetycznym (np. Bugnini 1990; Marini 2007), jak i te bardziej krytyczne (np. Bouyer 2015).

3 Mszał Rzymski z roku 1962 to ostatnie wydanie posługujące się tzw. starszym kalendarzem liturgicznym. Tenże kalendarz jest obowiązujący dla nadzwyczajnej formy rytu rzymskiego, jak tzw. liturgię trydencką określa motu proprio Summorum Pontificum (2007) Benedykta XVI. 
['Wszechmogący, wieczny Boże, który rządzisz wszystkimi rzeczami, zarówno w niebie, jak i na ziemi, miłosiernie/łaskawie wysłuchaj błagania swego ludu i ześlij swój pokój na nasze czasy/obdarz nasze czasy pokojem']

Już na pierwszy rzut oka starsza wersja angielska (1973) jest znacznie krótsza zarówno od oryginału, jak i od pozostałych przekładów. Wspomniana wyżej stała część kolekt wspominająca dzieła Boże (w oryginale ,qui caelestia simul et terrena moderaris") zostaje całkowicie opuszczona. Nowsza wersja przywraca tę część w formie: „who govern all things, both in heaven and on earth" 'który rządzisz wszystkimi rzeczami zarówno w niebie, jak i na ziemi'. Skierowana do Boga prośba w thumaczeniu ICEL 1973 jest zubożona - pomija ona przysłówek clementer, obecny w polskim thumaczeniu (taskawie) oraz w ICEL 2010 (mercifully 'miłosiernie, łaskawie'), a także rzeczownik lud, sprowadzając populi tui raptem do zaimka our 'nasze'. Kolejne pominięcie to zaimek dzierżawczy tuam: o ile przekłady polski oraz nowszy angielski uwzględniają ten zaimek (swoim pokojem/ your peace), ICEL 1973 pomija pierwiastek nadprzyrodzony i wydaje się sprowadzać pojęcie pokoju wyłącznie do kategorii doczesnych. Od strony leksykalnej ICEL 1973 wyróżnia się tu użyciem codziennego czasownika show 'pokaż, wskaż' jako ekwiwalentu dla concedere 'udzielić, użyczyć'. Mszał polski i najnowszy angielski oddają ten czasownik za pomocą odpowiedników, które nie mają charakteru potocznego: obdarzyćlbestow.

Poniżej zestawienie oryginału i tłumaczeń - kolekta na XI niedzielę zwykłą: MR

Deus, in te sperantium fortitudo, invocationibus nostris adesto propitious, et, quia sine te nihil potest mortalis infirmitas, gratiae tuae praestasemper auxilium, ut, in exsequendismandatis tuis, et voluntate tibi et actione placeamus.

\section{ICEL 1973}

Almighty God, our hope and our strength, without you we falter. Help us to follow Christ and to live according to your will.

['Wszechmogący Boże, nasza nadziei i nasza mocy, bez ciebie słabniemy/chwiejemy się. Pomóż nam naśladować Chrystusa i żyć zgodnie z Twoją wolą’]

\section{PL 1986}

Boże, mocy ufających Tobie, bez Ciebie nic nie możemy uczynić, wysłuchaj nasze błagania i wspomagaj nas swoją łaską, aby nasza wola i nasze czyny były poddane Twoim przykazaniom.

\section{ICEL 2010}

O God, strength of those who hope in you, graciously hear our pleas, and, since without you mortal frailty can do nothing, grant us always the help of your grace, that in following your commands we may please you by our resolve and our deeds. 
['O Boże, mocy tych, którzy pokładają w Tobie nadzieję, wysłuchaj łaskawie naszych próśb, a ponieważ bez Ciebie śmiertelna słabość nic nie może uczynić, udzielaj nam zawsze pomocy swej łaski tak, żebyśmy podążając za Twymi nakazami/ przykazaniami mogli Ci się podobać przez nasze postanowienia i czyny']

Podobnie jak poprzednia, powyższa kolekta w wersji ICEL 1973 to w pierwszym rzędzie przykład redukcji i odejścia od literalnego znaczenia względem tekstu oryginalnego, a także trywializacji języka przez dobór słownictwa. Typowa dla kolekt formuła błagalna (w polskim wydaniu „wysłuchaj nasze błagania i wspomagaj nas swoją łaską") zostaje w istocie opuszczona, ponieważ trudno za nią uznać banalne help us 'pomóż nam'. Trzecie wydanie mszału w języku angielskim proponuje wersję, która jest bardziej rozbudowana niż polski tekst z 1986 roku: ,graciously hear our pleas ... and ... grant us always the help of your grace”. Starszy przekład angielski pomija pojęcie łaski w kierowanej do Boga prośbie w łacińskim wydaniu typicznym gratiae tue, w polskiej modlitwie swoja łaska, w ICEL 2010 your grace. Przekład angielski z 1973 roku zawiera też daleko posunięte uogólnienie - mówi wprawdzie o życiu zgodnym z wolą Bożą, ale nie wspomina o tym, iż ma to polegać na dostosowaniu ludzkiej woli i czynów do Bożych przykazań. Od strony organizacji tekstu powyższa kolekta ilustruje jeszcze jeden problem, który przewija się w tłumaczeniu z 1973 roku - brakuje gramatycznych wykładników wiążących ze sobą poszczególne części kolekty. Tutaj pierwsza - sama w sobie już zubożona - część kolekty w ogóle nie zostaje językowo powiązana $\mathrm{z}$ następującą po niej prośbą, co znajduje swój wyraz w interpunkcji: prośba pojawia się po kropce w wersji ICEL 1973.

Z kolei w kolekcie na sobotę IV tygodnia Wielkiego Postu mamy do czynienia $\mathrm{z}$ innego rodzaju odejściem od łacińskiego oryginału $\mathrm{w}$ angielskiej wersji 1973 roku Tym razem, autorzy przekładu dodają przydawkę gentle 'łagodny', narzucając swoją własną interpretację miłosierdzia Bożego. Jednocześnie pojawia się kolejne pominięcie, gdyż angielski tekst w starszej wersji sprowadza formułę dirigat corda nostra - wiernie oddane w dwóch pozostałych przedstawionych tu przekładach (PL 1986 i ICEL 2010) jako guide us 'kieruj nami'.

MR

Dirigat corda nostra, quaesumus, Domine, tuae miserationis operatio, quia tibi sine te placere non possumus.

ICEL 1973

Lord, guide us in your gentle mercy, for left to ourselves we cannot do your will.

['Panie, kieruj nami w swym łagodnym miłosierdziu, bo zostawieni sami sobie nie potrafimy pełnić Twojej woli’] 
PL 1986

Miłosierny Boże, kieruj naszymi sercami, bo bez Twojej pomocy nie możemy się Tobie podobać.

\section{ICEL 2010}

May the working of your mercy, O Lord, we pray, direct our hearts aright, for without your grace we cannot find favor in your sight.

['Niech działanie Twojej łaski, o Panie, prosimy, kieruje naszymi sercami właściwie, ponieważ bez Twojej łaski nie możemy znaleźć zasługi w Twoich oczach’].

Odejście od języka sakralnego w tłumaczeniu ICEL 1973 i próbę powrotu do niego w nowszym przekładzie dobrze ilustruje także kolekta z III niedzieli Adwentu:

MR

Deus, qui conspicis populum tuum nativitatis dominicae festivitatem fideliter exspectare, praesta, quaesumus, ut valeamus ad tantae salutis gaudia pervenire, et ea votis sollemnibus alacri laetitia celebra re.

ICEL 1973

Lord God, may we, your people, who look forward to the birthday of Christ experience the joy of salvation and celebrate that feast with love and thanksgiving.

['Panie Boże, obyśmy my, Twój lud, którzy czekamy na narodziny Chrystusa, doznali radości zbawienia i obchodzili to święto z miłością i dziękczynieniem’]

\section{PL 1986}

Boże, Ty widzisz, z jaką wiarą oczekujemy świąt Narodzenia Pańskiego, spraw, abyśmy przygotowali nasze serca i z radością mogli obchodzić wielką tajemnicę naszego zbawienia.

\section{ICEL 2010}

O God, who see how your people faithfully await the feast of the Lord's Nativity, enable us, we pray, to attain the joys of so great a salvation, and to celebrate them always with solemn worship and glad rejoicing.

['O Boże, który widzisz, jak Twój lud wiernie oczekuje święta Narodzenia Pana, dozwól nam, prosimy, osiągnąć radość tak wielkiego zbawienia i zawsze obchodzić ją z uroczystą czcią i radością']

W wersji z 1973 roku podkreślone fragmenty to formy z języka codziennego, natomiast ich odpowiedniki z trzeciego wydania noszą znamiona stylu literackiego. Rzeczowniki birthday i love stoją tu w sporym kontraście do Nativity i wor- 
ship - te drugie w sposób oczywisty przynależą do terminologii religijnej. Ponadto, nowsza propozycja angielska nie stroni od użycia przydawek w postaci przymiotników great, solemn czy glad, z których zrezygnowano we wcześniejszym wydaniu. Warto nadmienić, że wersja polska również zawiera pewne skróty, choć nie dotykają one treści tak dalece, jak ma to miejsce w przypadku ICEL 1973. Podkreślmy jednak raz jeszcze, że przywołany polski przekład powstał przed opracowaniem trzeciej edycji typicznej, zatem trudno od niego wymagać, by był wiernym tłumaczeniem późniejszej wersji łacińskiej.

\section{Podsumowanie}

Omówione powyżej przykłady to zaledwie próbka tekstów ilustrujących dwie rozbieżne tendencje w przekładzie tekstów liturgicznych, tu omówione w kontekście języka angielskiego.

Nowszy przekład angielski odchodzi od niezwykle płytko pojmowanej „zrozumiałości" i przywraca tekstowi modlitw wymiar sacrum, a uczestnikom liturgii, włącznie z celebransem, udostępnia bogactwo treści, które kształtowały się na przestrzeni wieków, a których autorzy tłumaczenia z 1973 roku anglojęzycznych katolików pozbawili. Ujmując to inaczej, trzecia edycja mszału rzymskiego w języku angielskim, w przeciwieństwie do swej poprzedniczki, traktuje swego „odbiorcę" poważnie - otwiera przed nim bogactwo oryginału i zarazem stawia mu pewne wymagania.

Blisko 40 lat obcowania z tekstami modlitw odartymi z sacrum i pomijającymi istotne elementy doktryny musiało odcisnąć swoje piętno. Nie powinno zatem dziwić, iż wprowadzenie nowej wersji mszału w krajach anglojęzycznych poprzedzono szeroko zakrojoną akcją informacyjną i formacją katechetyczną, zarówno na poziomie episkopatów czy diecezji, jak również w wymiarze parafialnym. O punkcie wyjścia, wynikającym w dużej mierze z długoletniego posługiwania się wadliwym przekładem tekstów liturgicznych, mogą zaś świadczyć pojęcia, które biskupi amerykańscy uznali za stosowne przybliżyć wiernym, gdyż, jak to ujęto, „niektóre z nich mogą być nieznane niektórym katolikom”. Wśród wyjaśnianych terminów znalazły się między innymi: chalice 'kielich', consecration 'konsekracja', paschal 'paschalny', Incarnation 'wcielenie', Redemption 'odkupienie', damnation 'potępienie', justification 'usprawiedliwienie', patriarch 'patriarcha', oblation 'ofiara', contrite 'skruszony', venerate 'czcić'. Dostępne na stronie internetowej konferencji katolickich biskupów USA objaśnienia tych pojęć brzmią zaś jak wykład podstaw wiary rzymskokatolickiej. Taki poziom świadomości religijnej niemałej rzeszy anglojęzycznych katolików - choć oczywiście nie wszystkich spośród nich - wydaje się w ogóle podważać sensowność posoborowej reformy liturgicznej. Wszak wprowadzenie języków narodowych do liturgii

\footnotetext{
http://www.usccb.org/prayer-and-worship/the-mass/roman-missal/upload/words-in-the-roman-missal.pdf [dostęp: 10.09.2016].
} 
miało życie religijne katolików ubogacić i tajemnice wiary im przybliżyć, a nie „ukryć” je bądź wypaczyć w procesie przekładu. Trudno przeoczyć też fakt, iż spora część wspomnianych wyżej i wyjaśnianych anglojęzycznym katolikom słów to zapożyczenia łacińskie. To zaś budzi podejrzenie, że ich nieznajomość przynajmniej pośrednio bierze się z niemal całkowitego wyrugowania łaciny już nie tylko z obrzędów liturgicznych, ale nawet szerzej z życia współczesnego Kościoła.

W świetle powyższego można stwierdzić, iż język liturgii w rycie rzymskim stał się przynajmniej w pewnym stopniu ofiarą pędu ku zmianom, których Sobór wcale nie zalecał. W przypadku całkowitego zastąpienia łaciny językami narodowymi posoborowa reforma liturgiczna wyszła daleko poza wskazania Vaticanum II, a to, co się w tej materii dokonało, nie ma umocowania w dokumentach soborowych. Podobnie, w kwestii przekładu ksiąg liturgicznych, starsza angielska wersja tekstów mszalnych to przykład na to, co może się stać, gdy o kształcie liturgii pozwoli się decydować ludziom, którzy za swój nadrzędny cel uznają realizację swoich własnych wizji - dodajmy, wizji nie znajdujących poparcia w dokumentach Kościoła i jednocześnie kłócących się ze zdrowym rozsądkiem. Staraliśmy się to wykazać, siłą rzeczy w ograniczonym zakresie, na podstawie przedstawionych $w$ niniejszym opracowaniu przykładów kolekt w dwóch jakże różnych wersjach mszału rzymskiego w języku angielskim. Forsowany przez około 40 lat i nadal mający swych obrońców angielski przekład tekstów mszalnych jawi się jako wypaczenie postulatów Soboru Watykańskiego II, a nie ich realizacja.

\section{Bibliografia}

Bouyer L., 2015, The Memoirs of Louis Bouyer: From Youth and Conversion to Vatican II, the Liturgical Reform, and After, thum. J. Pepino, San Francisco.

Bugnini A., 1990, The Reform of the Liturgy 1948-1975, Collegeville.

Consilium for Implementing the Constitution on the Sacred Liturgy, 1969, Comme le prevoit On The Translation Of Liturgical Texts For Celebrations With A Congregation, http://www.ewtn.com/library/curia/conslepr.htm [dostęp: 07.10.2014].

Comme le prevoit On The Translation Of Liturgical Texts For Celebrations With A Congregation, 1969, http://www.ewtn.com/library/curia/conslepr.htm [dostęp: 07.10.2014].

Crystal D., 1964, A liturgical language in a linguistic perspective, „New Blackfriars”, nr 46, s. $148-156$.

Crystal D., 1990, Liturgical language in a sociolinguistic perspective, w: Language and the Worship of the Church, red. D. Jasper, R.C.D. Jasper, Basingstoke, s. 120-146.

Gamber K., 1992, La reforme liturgique en question, Le Barroux.

Elliot P.J., Liturgical translation. A question of truth, „Adoremus Bulletin” 2007, 13-4, http://www.adoremus.org/0607LiturgicalTranslation.html [dostęp: 13.05.2013].

Liturgiam authenticam. O stosowaniu języków narodowych przy wydawaniu ksiag rzymskiej liturgii, 2001, https://opoka.org.pl/biblioteka/W/WR/kongregacje/kkultu/instrukcja_liturgiam_28032001.html [dostęp: 07.10.2014].

Lang U.M., 2012, The voice of the Church at prayer. Reflections on liturgy and language, San Francisco. 
Marini P., 2007, A challenging reform. Realizing the vision of the liturgical renewal, red. M.R. Francis, J.R. Page, K.F. Pecklers, Collegeville.

Milcarek P., 2009, Historia Mszy. Przewodnik po dziejach liturgii rzymskiej, Dębogóra.

Missale Romanum ex decreto Sacrosancti Oecumenici Consilii Vaaticani II instauratum auctoritate Pauli PP.VI promulgatum Ioannis Pauli PP.II cura recognitum, 2002, editio typica tertia, Vaticanum.

Mohrmann C., 1959, Liturgical Latin: Its Origins and Character, London.

Mohrmann C., 1977, The Ever-Recurring Problem of Language in the Church, w: Etudes sur le latin des chrétiens, red. C. Mohrmann, t. 4, Rome, s. 143-159.

Mszał rzymski dla diecezji polskich, Poznań 1986, http://ministranci.waw.pl/wp-content/ uploads/docs/Mszal.pdf [dostęp: 07.10.2014]; skrót: PL 1986.

Nida E., 1964, Toward a science of translating, Leiden.

Sacrosanctum concilium. Konstytucja o liturgii świętej, 1963, http://www.kkbids.episkopat.pl/?id=87 [dostęp: 07.10.2014].

Pecklers K., 2003, Dynamic equivalence. The living language of Christian worship, Collegeville.

Pell G., 2014, Liturgical translations and two instructions in perspective. Cardinal Pell's address to Sacrosanctum Concilium conference, http://www.zenit.org/en/articles/cardinal-pell-s-address-to-sacrosanctum-concilium-conference [dostęp: 07.10.2014].

Pskit W., 2018, O języku liturgii rzymskokatolickiej na przykładzie angielskiej wersji Mszału Pawła VI, w: Intertekstualność a Słowo Boże, czyli o języku biblijno-religijnym w tekstach kultury. Czesść II, red. M.K. Frąckiewicz i A.J. Najda, Warszawa, s. 179-196.

Reid A., 2005, The organic development of the liturgy, San Francisco.

Ratzinger J., 2002, Duch liturgii, thum. E. Pleciul, Poznań.

Roman Missal: Revised by Decree of the Most Holy Second Ecumenical Council of the Vatican, Promulgated by Authority of Pope Paul VI and Revised at the Direction of Pope John Paul II. Totowa, 2011, New York.

Roman Missal: Revised by Decree of the Second Vatican Council and Published by Authority of Pope Paul VI, 1974, London.

Schuler R.J., 1981, „Success” of the liturgical reform, „Sacred Music”, nr 108-4, s. 3-4.

Inter oecumenici. Instrukcja o należytym wykonywaniu konstytucji o liturgii świętej, 1964, http://www.kkbids.episkopat.pl/?id=89 [dostęp: 07.10.2014].

Zachara M., 2014, Krótka historia Mszatu Rzymskiego, Warszawa.

\section{WYKAZ SKRóTÓW}

ICEL 1973 - Roman Missal: Revised by Decree of the Second Vatican Council and Published by Authority of Pope Paul VI, 1974, London.

ICEL 2010 - Roman Missal: Revised by Decree of the Most Holy Second Ecumenical Council of the Vatican, Promulgated by Authority of Pope Paul VI and Revised at the Direction of Pope John Paul II. Totowa, 2011, New York.

MR - Missale Romanum ex decreto Sacrosancti Oecumenici Consilii Vaaticani II instauratum auctoritate Pauli PP.VI promulgatum Ioannis Pauli PP.II cura recognitum, 2002, editio typica tertia, Vaticanum. 
